\title{
The Politics of Nationalism and Ethnicity
}


Also by James Kellas

The Scottish Political System

Modern Scotland 


\title{
The Politics of Nationalism and Ethnicity
}

\author{
Second Edition
}

James G. Kellas 
(C) James G. Kellas 1991, 1998

All rights reserved. No reproduction, copy or transmission of this publication may be made without written permission.

No paragraph of this publication may be reproduced, copied or transmitted save with written permission or in accordance with the provisions of the Copyright, Designs and Patents Act 1988 , or under the terms of any licence permitting limited copying issued by the Copyright Licensing Agency, 90 Tottenham Court Road, London W1P 9HE.

Any person who does any unauthorised act in relation to this publication may be liable to criminal prosecution and civil claims for damages.

The author has asserted his right to be identified as the author of this work in acccordance with the Copyright, Designs and Patents Act 1988.

First edition 1991

Reprinted three times

Second edition 1998

Published by

MACMILLAN PRESS LTD

Houndmills, Basingstoke, Hampshire RG21 6XS

and London

Companies and representatives throughout the world

ISBN 978-0-333-73193-2

ISBN 978-1-349-26863-4 (eBook)

DOI 10.1007/978-1-349-26863-4

A catalogue record for this book is available from the British Library.

This book is printed on paper suitable for recycling and made from fully managed and sustained forest sources.

$\begin{array}{rrrrrrrrrr}10 & 9 & 8 & 7 & 6 & 5 & 4 & 3 & 2 & 1 \\ 07 & 06 & 05 & 04 & 03 & 02 & 01 & 00 & 99 & 98\end{array}$

Published in the United States of America 1998 by

ST. MARTIN'S PRESS, INC.,

Scholarly and Reference Division,

175 Fifth Avenue, New York, N.Y. 10010

ISBN 978-0-312-21553-8 


\section{Contents}

List of Tables vii

Acknowledgements $\quad$ ix

Preface to the Second Edition $\quad$ xi

$\begin{array}{ll}\text { Introduction } & 1\end{array}$

1 Ethnicity and Human Nature 11

2 Nationalism as Ideology 27

3 The Evolution of Nationalism 43

4 Ethnic and Social Nationalism 65

5 Nationalist Movements and Ethnic Politics $\quad 89$

6 Nationalism in the Western World 105

Western Europe 105

Quebec 115

Ethnic politics in the US and Britain 119

7 Nationalism in the Former Communist States 129

The former USSR 130

Yugoslavia and its breakaway nations $\quad 141$

The former Czechoslovakia 146

8 Nationalism in the Developing World, South Africa, and the Middle East 153

Sri Lanka and the Indian sub-continent 154

Black Africa $\quad 161$

South Africa: Apartheid and its overthrow 164

Zionism and Palestinian Nationalism 169 
9 Cultural Pluralism and the Politics of Accommodation

10 Nationalism and International Relations 189

11 Conclusion: An Integrated Theory of the Politics of Nationalism and Ethnicity

Synopsis of Theory

Bibliography

Index 


\section{List of Tables}

1.1 Scottish national identity, $1986 \quad 22$

1.2 Single and multiple national identities in England, Wales and Scotland, 1997

1.3 Catalan national identification, $1979 \quad 24$

3.1 Politics, the economy, and culture and nationalism $\quad 45$

4.1 Ethnic and social nationalism 68

6.1 Catalan elections $\quad 110$

6.2 Basque country (Euskadi) elections 111

10.1 'Net favourability' of attitudes in Britain and France towards other countries 205

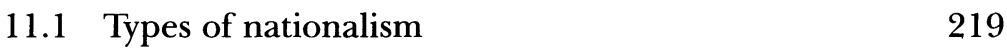




\section{Acknowledgements}

I first studied nationalism as an undergraduate student of Joseph Frankel at the University of Aberdeen in 1957-8, and later specialised in the study of Scottish politics as a university lecturer. Once more, the subject of nationalism came to the fore, in the form of Scottish nationalism. As a Visiting Professor of Political Science at the University of Pittsburgh in 1985-6, I taught a course on nationalism generally, and had regular discussions on the subject with Richard Cottam (an expert on Middle East nationalism), Dennison Rusinow (an historian with a particular interest in Balkan nationalism) and Christina Paulston (a linguist specialising in language survival). These sessions broadened my perspective considerably.

At the University of Glasgow, I have kept up a continuous discourse on nationalism with colleagues, many of whom are experts on political theory and the study of particular areas of the world. Most of these will perhaps be surprised at the content of this book, and perhaps alarmed. I hope they do not mind my thanking them here, but they are of course not a party to what I have written.

Special thanks are due to Avril Johnstone, who coped with the frequent revisions during the production of the original typescript.

JAMES G. KeLlaS 


\section{Preface to the Second Edition}

Since the first edition was published in 1991, much of the material contained in it has had to be changed and updated. The USSR has disintegrated into its 'national' components, as have Yugoslavia and Czechoslovakia. In general, the eastern European communist bloc has been replaced by independent nation-states, each showing its own strong nationalism. Meanwhile, in the rest of Europe, nationalism vied with the supranational European Union for the loyalty of governments and peoples. Again, nationalism showed its continuing strength in the face of integration. The old states, such as Britain, France, Spain, Belgium and Canada, continued to be threatened by nationalisms within them, but none broke up entirely. Nationalist and ethnic conflict continued unabated in Africa and Asia.

Apart from updating, there has been some alteration of emphasis. There is more specifically on politics and less on other aspects of nationalism and ethnicity which do not impinge clearly on politics. A somewhat different approach has been adopted for international relations, to take account of the effect that international society has on nationalism in aspiring nation-states, notably those in the former states of Yugoslavia, Czechoslovakia and the USSR. This 'top-down' view can be contrasted with the 'bottom-up' perspective, which sees international society as the product of nationalism.

The theory presented has not been altered, but account has been taken of criticisms by some reviewers. It is true that the theory is as much a collection of interlocking and interdependent aspects of nationalism as an hypothesis which can be falsified, unless one rejects entirely one or more of its 'building-blocks'. For example, some would remove the block which links nationalism to aspects of human nature. The problem is: what evidence can be found to verify or falsify this (or any other) part of theory? As the study of human genes progresses rapidly, we shall no 
doubt be able in the future to determine if our genes are in any way related to ethnocentric and nationalist behaviour.

As for politics, the period since the first edition has amply demonstrated that nationalism and ethnicity are as relevant at the end of the twentieth century as at any other time in history.

JAMES G. KellaS 